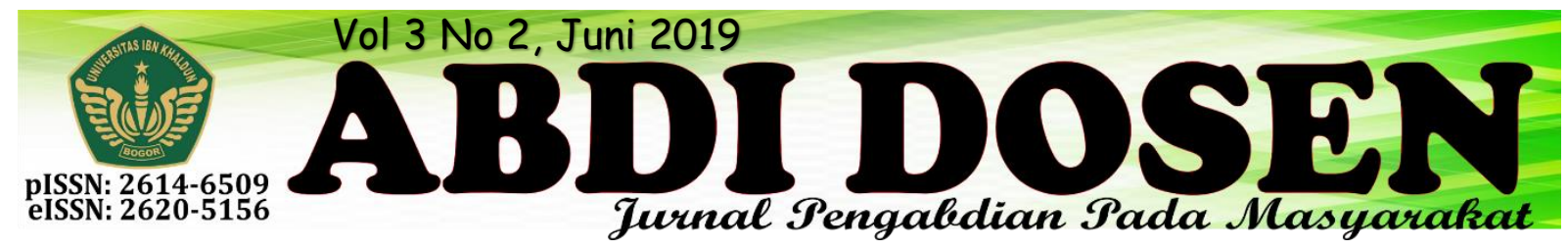

\title{
MEMBENTUK KEPRIBADIAN YANG BERPENDIDIKAN SERTA KESADARAN DIRI DALAM MENUNTUT ILMU DI KAMPUNG SINAR WANGI
}

\author{
Fety Fatimah ${ }^{1}$, Alvian Nuradiyantoro ${ }^{2}$ \\ fety.fatimah@ft.uika-bogor.ac.id ${ }^{1}$ \\ nuralvian21@gmail.com ${ }^{2}$ \\ Fakultas Teknik Universitas Ibn Khaldun, Mahasiswa KKN Kelompok 06 Tahun $2018^{2}$
}

\begin{abstract}
ABSTRAK
Kampung Sinar Wangi Desa Tapos Satu Kecamatan Tenjolaya Kabupaten Bogor merupakan salah satu tempat yang di pilih dan ditunjuk oleh LPPM untuk menjadi tempat pelaksanaan Kuliah Kerja Nyata yang bertemakan Tematik Terintegrasi. Kurangnya kepedulian masyarakat di Kampung Sinar Wangi dalam bidang pendidikan berdampak pada keinginan dan antusiasme anak-anak terhadap pendidikan itu sendiri. Hal ini dapat dilihat dari kurangnya kesadaran para orang tua untuk melanjutkan pendidikan anak-anak ke jenjang yang lebih tinggi lagi. Kesadaran diri para orang tua yang dibatasi juga oleh kebutuhan ekonomi membuat mereka berhenti bersekolah dan hanya bertamatkan ijazah sekolah dasar. Maka dari itu tema yang kami garap adalah "Membentuk Kepribadian Yang Berpendidikan Serta Kesadaran Diri Dalam Menuntut Ilmu Di Kampung Sinar Wangi” agar permasalahan yang terjadi di kampung sinar wangi dapat teratasi sedikit demi sedikit. Maka dari itu kami juga membentuk 4 pilar untuk mendukung adanya program tersebut yaitu 1. Pilar Pendidikan, 2.Pilar Ekonomi, 3.Pilar Kesehatan, 4.Pilar Pemberdayaan Lingkungan.
\end{abstract}

Kata Kunci : Pendidikan, Kepribadian Berpendidikan, Kesadaran Diri, 4 Pilar.

\section{PENDAHULUAN}

Kuliah Kerja Nyata merupakan program pendidikan dengan memberikan pengajaran kepada mahasiswa untuk beradaptasi dengan masyarakat. Ada beberapa tahap diantaranya persiapan, pembekalan, observasi sampai pada tahap evaluasi. Persiapan merupakan kegiatan sebelum KKN dilaksanakan, persiapan dilakukan agar kegiatan dapat terlaksana dengan dengan terstruktur dan terarah serta tepat pada sasaran. Persiapan dilakukan oleh pihak LPPM selaku koordinator dan mahasiswa sebagai peserta KKN. Tujuan dari KKN sendiri adalah mahasiswa diharapkan dapat memberikan bantuan pemikiran, tenaga, dan ilmu pengetahuan dalam merencanakan dan melaksanakan program memajukan desa.

Tujuan kegiatan pembekalan KKN adalah membekali mahasiswa dengan materi pemberdayaan masyarakat melalui KKN dan materi teknis kegiatan KKN. Melalui koordinasi dengan Dosen Pembimbing Lapangan (DPL) KKN kelompok secara efektif. Mahasiswa KKN juga mengadakan pertemuan rutin untuk membahas program kerja.

Ketika mahasiswa berada di lokasi KKN, para mahasiswa melakukan kegiatan survey. Kegiatan ini dilakukan untuk 
mengamati secara langsung terhadap permasalahan apa yang sedang dihadapi masyarakat dan mahasiswa diharapkan dapat memecahkan permasalahan tersebut. Inilah yang yang disebut Kuliah Kerja Nyata Tematik Terintegrasi.

Dan salah satu tempat yang di pilih dan di tunjuk oleh LPPM sebagai tempat pelaksanaan Kuliah Kerja Nyata yang bertemakan Tematik Terintegrasi adalah Desa Tapos Satu Kecamatan Tenjolaya. Anggota kelompok 06 berjumlah 14 orang yang berasal dari fakultas dan jurusan yang berbeda-beda. Berdasarkan hasil survey yang dilakukan di desa tapos satu, di pilihlah satu kampung yaitu Kampung Sinar Wangi dengan RW sasaran yaitu RW 07 RT 4. Desa tapos satu dan kampung sinar wangi mempunyai masyarakat yang heterogen atau beragam, sehingga dalam penyusunan serta perencanaan suatu program disesuaikan dengan kondisi, situasi dan potensi yang dimiliki oleh lokasi setempat. Setelah melihat hasil survey dan menganalisis daerah maka Tim KKN kelompok 06 memilih untuk menyusun program yang mencakup empat pilar utama yaitu, Pendidikan, Ekonomi, Kesehatan dan Pemberdayaan Lingkungan. Kondisi masyarakat di kampung sinar wangi cukup produktif di luar dari bidang pertanian itu sendiri, seperti kegiatan pengajian rutin, posyandu, gotong royong sampai ke daerah wisata.

\section{Keadaan Geografis}

Kampung Sinar Wangi merupakan salah satu kampung di Desa Tapos Satu Wilayah Kecamatan Tenjolaya Kabupaten Bogor, yang terbagi dalam 7 Rukun Warga (RW) dan 5 Rukun Tetangga (RT). Batas wilayah kampung sinar wangi adalah sebagai berikut :

\begin{tabular}{|c|c|l|}
\hline No & Arah & \multicolumn{1}{|c|}{ Perbatasan } \\
\hline 1 & Utara & Desa Cibitung Tengah \\
\hline 2 & Selatan & $\begin{array}{l}\text { Kampung Sindang } \\
\text { Resmi }\end{array}$ \\
\hline 3 & Timur & $\begin{array}{l}\text { Desa Gn. Malang/ Gn. } \\
\text { Mulya }\end{array}$ \\
\hline 4 & Barat & $\begin{array}{l}\text { Desa Cibening/ Gn. } \\
\text { Bunder }\end{array}$ \\
\hline
\end{tabular}

\section{Kondisi Masyarakat}

Jumlah penduduk desa tapos satu untuk Rw 07 berjumlah 1.827 Jiwa yang terdiri dari:

\begin{tabular}{|c|c|c|c|c|c|c|l|}
\hline No & RW & RT & KK & Laki-laki & Perempuan & Jumlah & \multicolumn{1}{|c|}{ Ket } \\
\hline 1 & 07 & 01 & 122 & 251 & 248 & 499 & Kp. Babakan \\
\hline 2 & 07 & 02 & 155 & 244 & 304 & 548 & Kp. Jagapati \\
\hline 3 & 07 & 03 & 47 & 95 & 88 & 183 & Kp. Sindang Resmi \\
\hline 4 & 07 & 04 & 80 & 143 & 143 & 286 & Kp. Sinar Wangi \\
\hline 5 & 07 & 05 & 74 & 154 & 157 & 311 & Kp. Sinar Wangi \\
\hline
\end{tabular}

\section{Keadaan Ekonomi}

Keadaan mata pencaharian penduduk kampung sinar wangi adalah sebagian besar sebagai petani. Daerah tersebut sangat banyak ditanami oleh hasil untuk lalapan, salah satu contohnya adalah petani popohan dan kucai. Terdapat juga petani kentang yang tidak banyak hanya beberapa dari kebanyakan petani lalapan. 
Daun Poh-pohan yang nama ilmiahnya adalah Pilea Trinervia atau sinonimnya Pilea melastomoides, mungkin hanya bisa kita jumpai di Jawa Barat saja, karena kebanyakan orang Sunda yang sangat menyukai daun Poh-pohan ini. Pohpohan ternyata mengandung antioksidan yang berkhasiat untuk mengurangi akumulasi radikal bebas, menetralisir racun, mencegah inflamasi dan melindungi penyakit genetik. Disamping itu Pohpohan mengandung falvonoid yang tinggi sehingga bisa digunakan sebagai anti kanker. Kandungan kalsium dalam tumbuhan ini sebesar 744,0 mg/100 gram. Daun pohpohan juga bisa berguna sebagai obat kecantikan.

Adapun daun Kucai atau Allium schoenoprasu dikenal juga dengan sebutan chive, bawang ganda dan gow choy, termasuk dalam jenis tanaman bawangbawangan. Tanaman ini bergerombol seperti tanaman padi yang baru tumbuh. Warna bunganya ungu dan bentuknya pipih, padat dan tidak berlubang. Aroma bawang yang lembut dari tanaman yang di ambil daunnya saja ini selain menambah cita rasa pada hidangan, juga berfungsi untuk menurunkan tekanan darah dan merangsang nafsu makan, mengeluarkan dahak/lendir. Bagian daun yang baik digunakan adalah daun yang masih muda berwarna hijau tua.

\section{METODE PENGABDIAN}

Konsep membentuk kepribadian yang berpendidikan serta kesadaran diri dalam menuntut ilmu banyak definisi yang dikemukakan oleh para ahli yang memiliki kepedulian tinggi terhadap kemajuan pendidikan di masyarakat, seperti yang

\section{Keadaan Pendidikan dan Kesehatan}

Keadaan pendidikan di kampung sinar wangi kurang begitu bagus di karenakan kesadaran diri yang terdapat pada orang tua sangat minim sebab karena keterbatasan biaya dalam hal ekonomi. Kesadaran diri itu perlu apalagi menyangkut soal anak dan kewajiban serta haknya dalam menuntut ilmu. Menurut Freud bahwa kesadaran hanyalah sebagian kecil dari seluruh kehidupan psikis. Psikis diibaratkan fenomena gunung es di tangah lautan luas yang ada dalam alam sadar atau kesadaran, sedangkan yang berada dibawah permukaan air laut dan merupakan bagian terbesar adalah hal-hal yang tidak disadari atau ketidaksadaran. Menurut Freud di dalam ketidaksadaran inilah terdapat kekuatan-kekuatan dasar yang mendorong pribadi. Freud mengemukakan teori topografi tentang kesadaran. Tingkat kesadaran menurutnya dibagi menjadi 3 daerah, yaitu : alam sadar, alam prasadar, dan alam tak sadar.

Adapun dari segi kesehatan adalah bahwa kesehatan merupakan keadaan sejahtera dari badan, jiwa, dan sosial yang memungkinkan setiap orang hidup produktif secara sosial dan ekonomis. Segi kesehatan di kampung sinar wangi pun miris karena terdapat anak yang menderita gizi buruk. Beberapa anak yang menderita gizi buruk berasal dari keluarga yang tidak mampu dan tidak bisa membawa serta memeriksakan keadaan atau kondisi anaknya lebih jauh lagi ke dokter.

dikemukakan oleh Prof. Sasmoko pada dasarnya jiwa manusia dibedakan menjadi dua aspek, yakni aspek kemampuan (ability) dan aspek kepribadian (personality). Aspek kemampuan meliputi prestasi belajar, intelegensia, dan bakat, 
sedangkan aspek kepribadian meliputi watak, sifat, penyesuaian diri, minat, emosi, sikap, dan motivasi.

Perlunya upaya membentuk kepribadian yang berpendidikan adalah berangkat dari kenyataan masih lemahnya kesadaran diri sebagian besar masyarakat terutama orang tua dalam menuntut hak dan menjalankan kewajibannya

\section{REALISASI PROGRAM}

Pelaksanaan program kerja KKN 06 selama 1 bulan terhitung mulai tanggal 07 Agustus - 07 September 2018 di Kampung Sinar Wangi RT04/RW07 Desa Tapos Satu Kecamatan Tenjolaya Kabupaten Bogor adalah sebagai berikut:

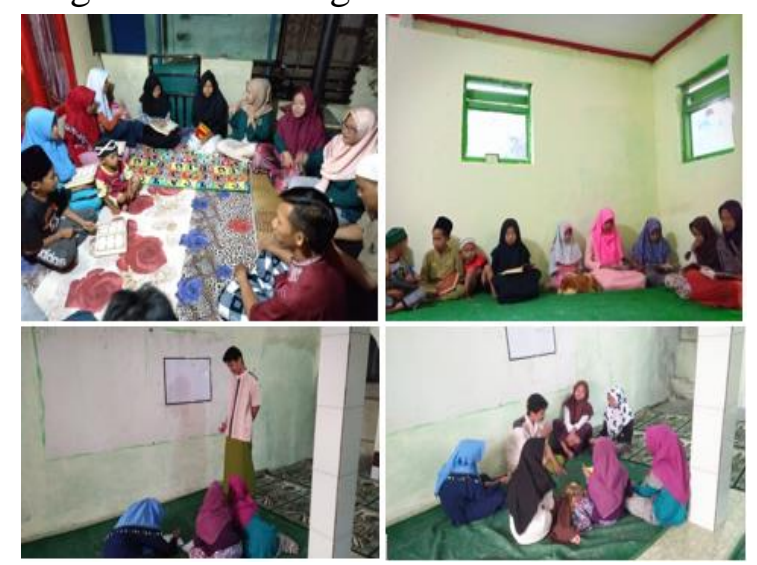

\section{TPA (Taman Pengajian Anak-anak)}

TPA (Taman Pengajian Anak-anak) merupakan wadah yang berfungsi untuk menjembatani dan memfasilitasi anak-anak dalam mempelajari Iqro, Juz Am'ma atau Al-Quran dengan baik dalam cara membaca maupun menulis Al-Quran. Program ini dilaksanakan oleh bidang pendidikan dan bidang agama islam setiap hari senin-jumat di waktu sore hari pukul 15.30 WIB s/d selesai bertempatkan di Mushola Al-Amin kampung sinar wangi. ditunjukkan dengan kurang memberikan pendidikan yang layak terhadap anaknya, misalnya terhadap beberapa fasilitas: metode pembelajaran, motivasi pendidikan, dan bimbingan belajar. Kondisi tersebut yang akan kita selesaikan dalam tingkat pendidikan yang dimiliki oleh masyarakat terutama yang ada di Kampung Sinar Wangi.

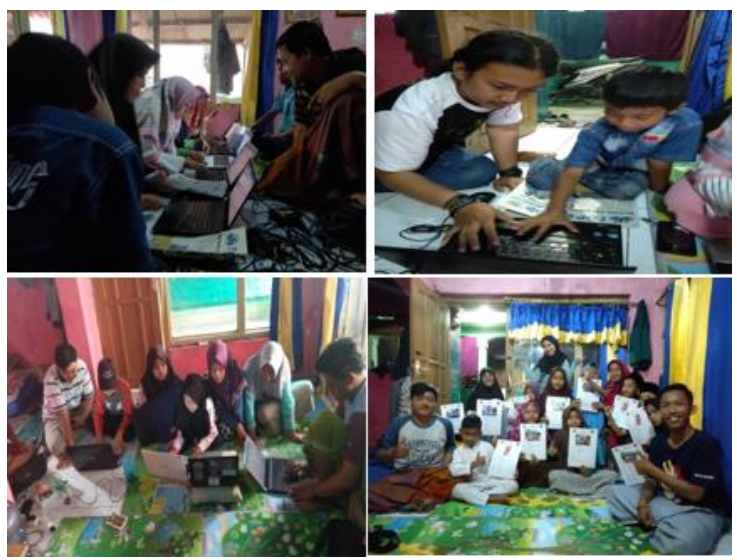

\section{Pelatihan Komputer}

Pelatihan komputer merupakan sebuah wadah yang berfungsi untuk menjembatani siswa/siswi yang mengalami kesulitan dalam mengoperasikan komputer, mengingat pendidikan masa kini telah berbasis teknologi maka sangat diharapkan masyarakat mampu menguasai cara kerja komputer.

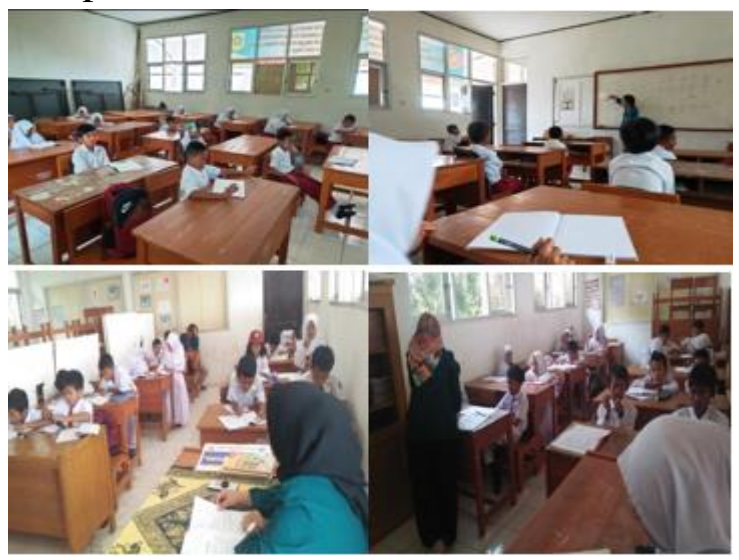

\section{Bimbingan Belajar}

Bimbingan belajar merupakan sebuah wadah yang berfungsi untuk menjembatani siswa/siswi serta anak-anak yang putus 
sekolah untuk tetap dapat belajar dan merasakan ilmu pengetahuan agar termotivasi kembali bahwa mereka masih bisa merasakan suasana belajar mengajar di masa sekolah dan tetap mengejar citacitanya.

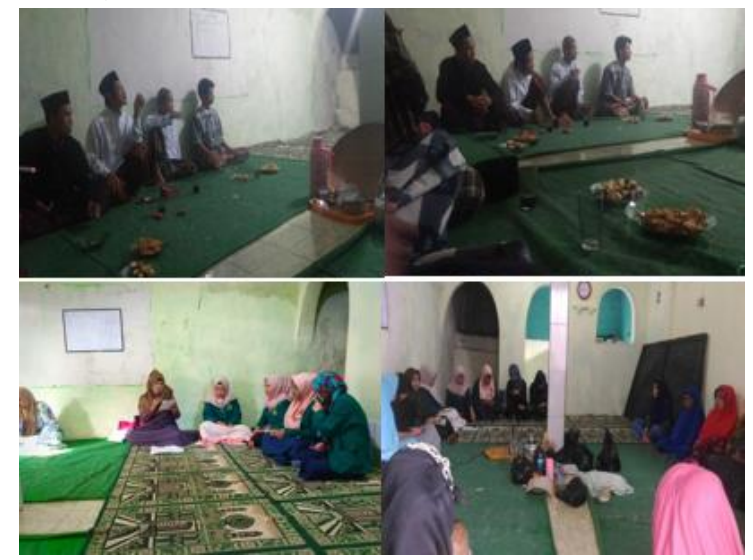

Pengajian Orang Tua (Bapak-bapak, Pemuda dan Ibu-ibu)

Pengajian orang tua merupakan suatu kegiatan rutin yang dilakukan oleh masyarakat kampung sinar wangi yang dilaksanakan setiap hari minggu pagi untuk ibu-ibu dan minggu malam untuk bapak-bapak dan pemuda.

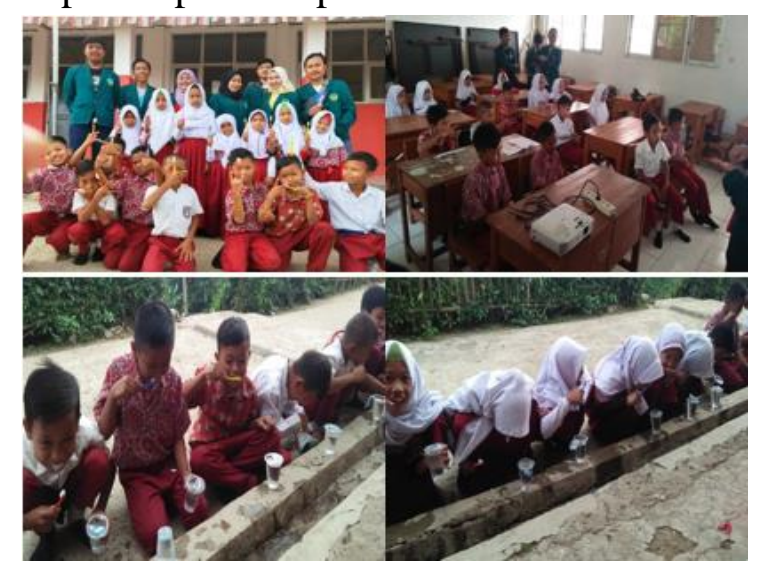

Penyuluhan PHBS (Cuci Tangan \& Sikat Gigi)

PHBS merupakan sebuah singkatan dari Perilaku Hidup Bersih Sehat adalah kegiatan yang harus dilakukan oleh setiap orang, baik di dalam rumah atau dimana pun dalam hal kebersihan dan kesehatan dirinya sendiri agar terhindar dari kuman, bakteri, virus dan penyakit. PHBS juga berfungsi untuk mencegah penyakit agar tidak hinggap di tubuh kita. Contoh PHBS salah satunya adalah cuci tangan dan sikat gigi.

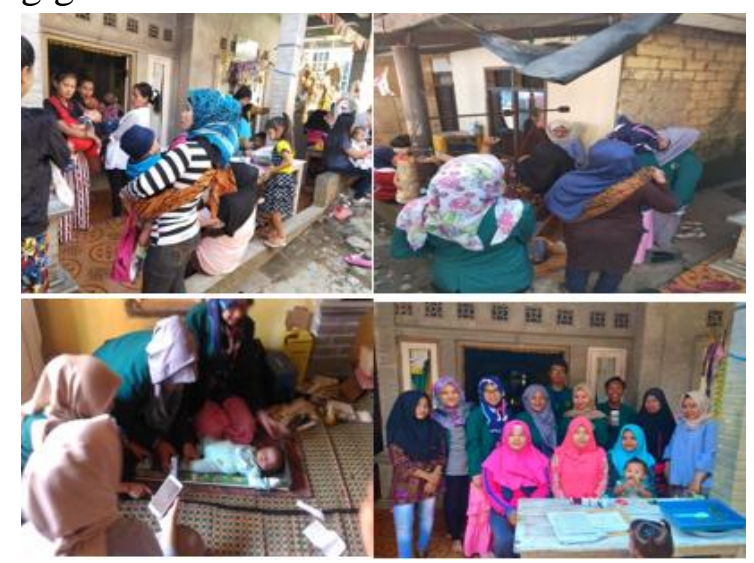

\section{Penyuluhan Posyandu}

Penyuluhan posyandu juga bagian dari kesehatan diri kita, dimana sudah seharusnya sejak dini diri kita sudah di imunisasi agar terhindar dari penyakit dan memiliki daya tahan tubuh. Posyandu di kampung sinar wangi di adakan setiap satu bulan sekali dengan agenda yang berbedabeda.

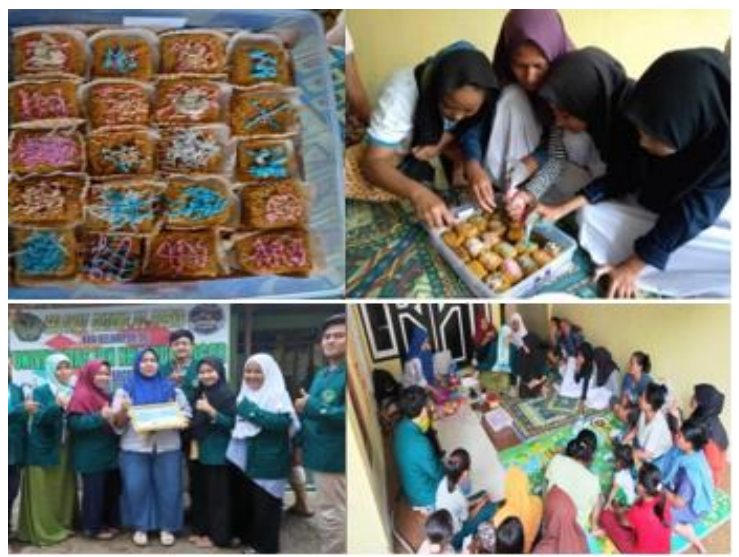

Pelatihan Kewirausahaan (Pembuatan Pisang Nugget)

Pelatihan pembuatan pisang nugget merupakan sebuah kegiatan yang berguna untuk ibu-ibu rumah tangga. Karena dengan adanya pelatihan ini mereka dapat mengolah makanan cepat saji yang murah dan bisa mendapatkan untung yang banyak. Juga mampu memberikan inspirasi kepada ibu rumah tangga bahwa sebuah pisang bisa diolah jadi berbagai macam 
makanan dengan cara yang sederhana dan budget yang murah.

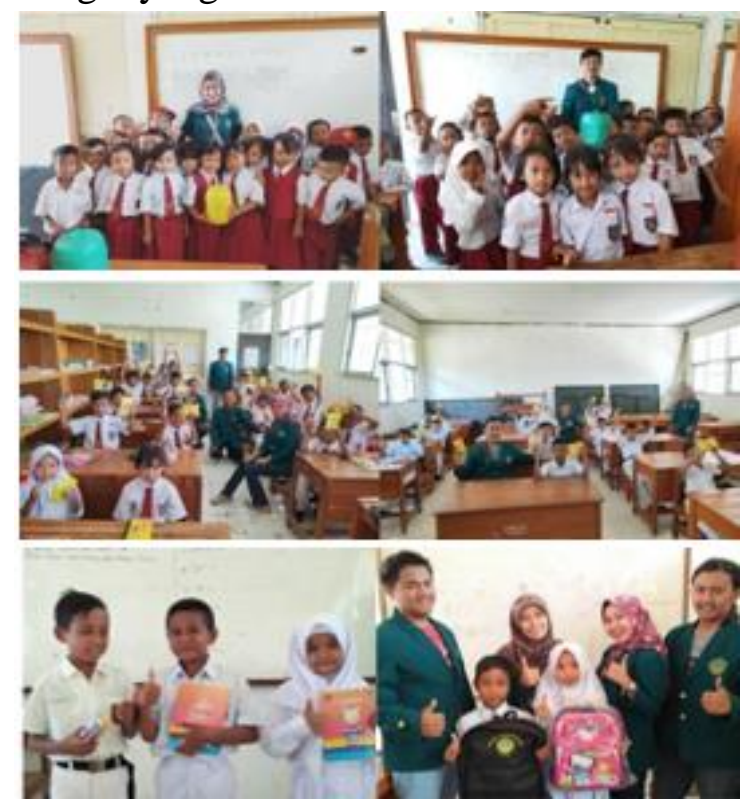

\section{Perlombaan Menabung}

Kami melaksanakan perlombaan menabung dari tanggal 13 agustus sampai dengan 5 september 2018 kami juga memberikan pemaparan kepada siswasiswi kelas 1, 2 ,3, 4, 5 dan 6 di sekolah agar bisa menabung atau menyisihkan uangnya dengan menabung, memberikan penjelasan tentang seberapa penting menanamkan budaya menabung sejak dini. Kami pun akan memberikan hadiah kepada kelas yang mendapatkan hasil tabungan paling banyak sampai waktu yang kita tentukan.

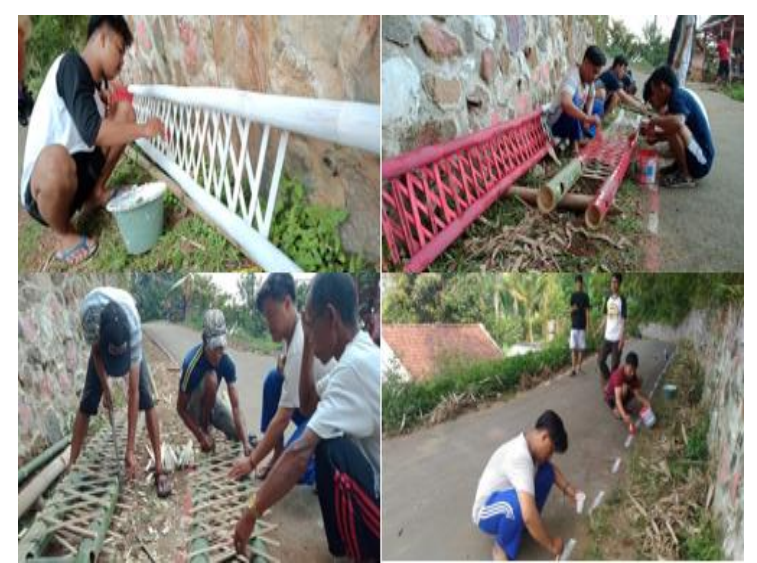

\section{Pembuatan Umbul-umbul dan Gapura}

Dalam memperingati HUT RI ke-73 kami mahasiswa KKN UIKA bogor bersama masyarakat kampung sinar wangi membuat gapura dan menghias jalan untuk memeriahkan hari ulang tahun Negara Kesatuan Republik Indonesia.

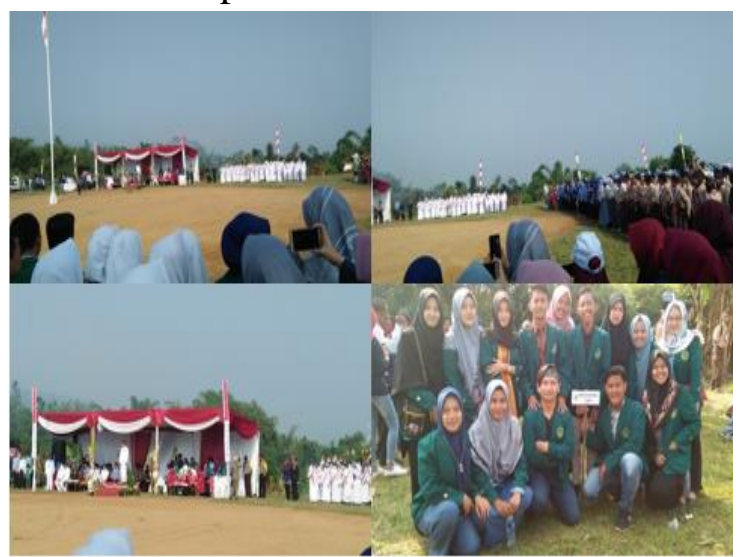

\section{Upacara Peringatan HUT RI Ke-73}

Dalam Menyambut peringatan hari ulang tahun Negara Kesatuan Republik Indonesia yang ke 73 kami kelompok yang bertempatkan di kecamatan tenjolaya mengikuti upacara bendera hari kemerdekaan nasional pada tanggal 17 agustus 2018 yang berlokasi di desa gunung malang. 


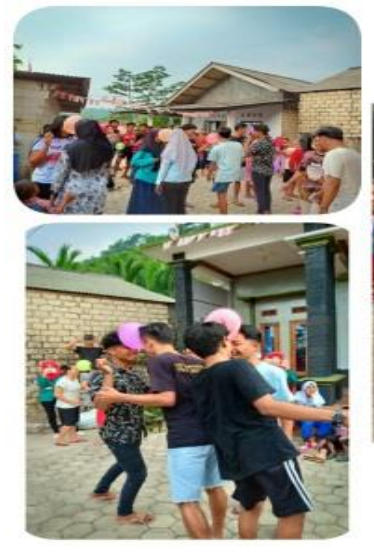

\section{Lomba}

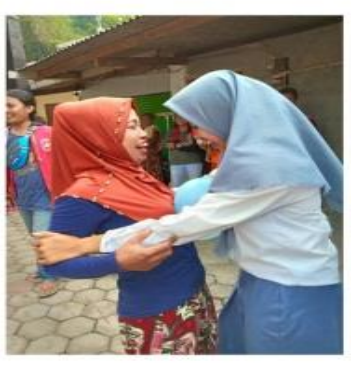

Joget Balon

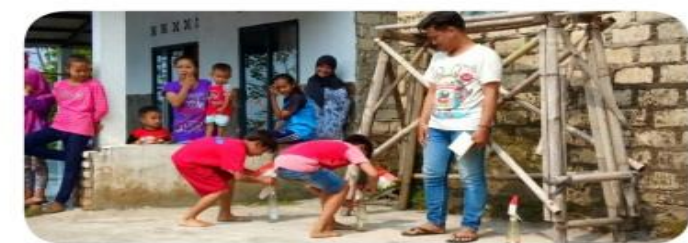

Lomba Bendera \& Pakm Botol
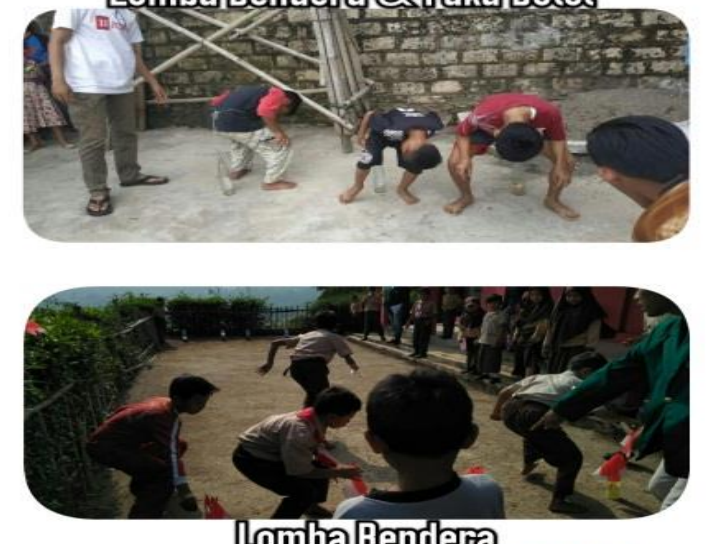

Lamba Bendera

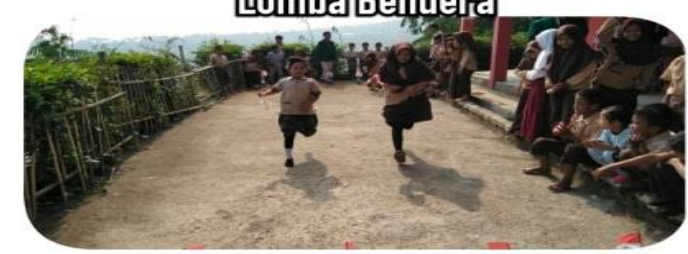

\section{Peringatan 17 Agustus}

Tepat pada tanggal 17 agustus 2018 hari jumat pukul 13.00 WIB kami memeriahkan hari ulang tahun Negara Indonesia dengan melakukan beberapa kegiatan perlombaan yang di ikuti oleh warga kampung sinar wangi. Dan kami juga melakukan perlombaan di SD Sinar Wangi pada tanggal 16 agustus 2018 hari kamis pada pukul 10.00 WIB yang di ikuti oleh seluruh siswa/siswi SD Sinar Wangi.

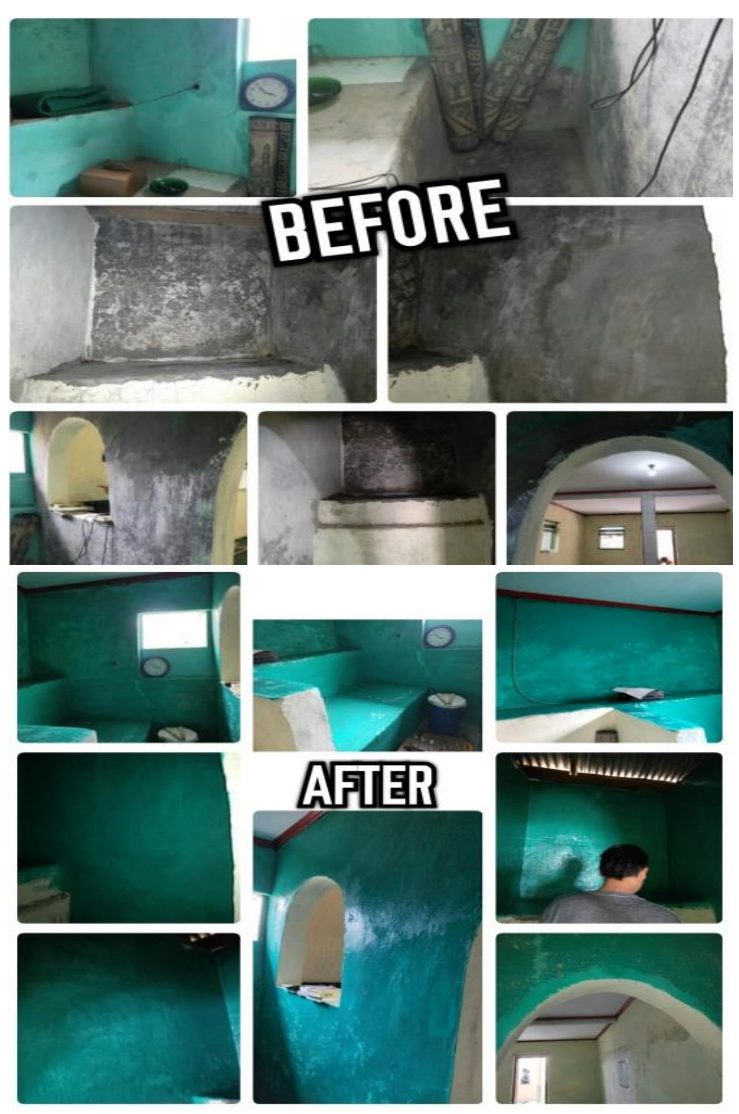

\section{Renovasi Mushola}

Mushola Al-Amin adalah salah satu mushola yang terdapat di kampung sinar wangi. Setiap harinya mushola tersebut dijadikan sebagai tempat untuk mengaji anak-anak sore hari dan pada minggu pagi oleh ibu-ibu juga minggu malamnya oleh bapak-bapak dan pemuda.jika ditelusuri kedalam ternyata masih ada bagian yang belum tampak rapih jadi kami berniat untuk merenovasi dan membaguskan sedikit mushola yang sering dipakai oleh warga sinar wangi. 


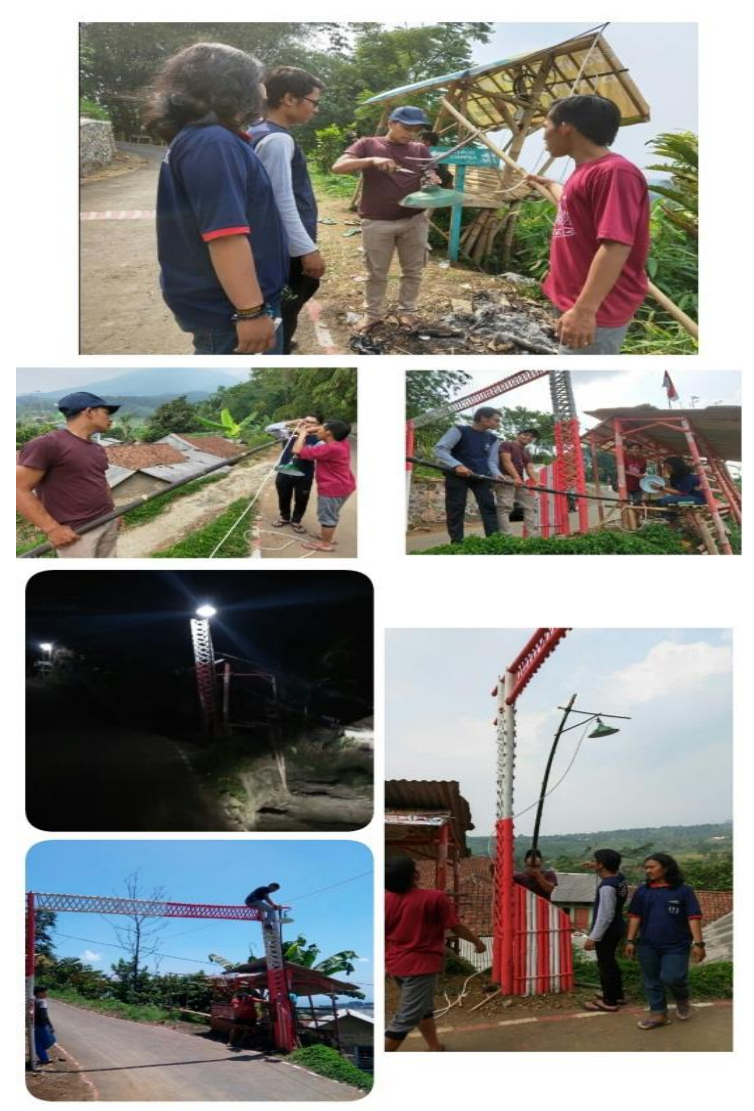

Pembuatan Lampu Penerangan Jalan

Di desa sinar wangi sangat minim akan penerangan jalan selain itu juga rawan untuk keadaan malam hari dan berbahaya untuk kendaraan bermotor dengan jarak pandang yang cukup parah karena kurangnya lampu penerangan jalan. Maka itu dari berinisiatif untuk membuat lampu penerangan jalan yang selalu dilewati oleh warga sekitar.
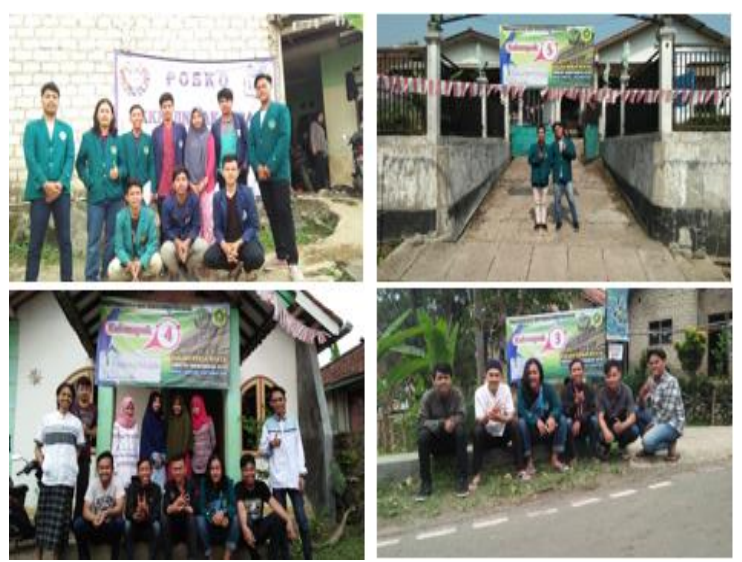

\section{Kunjungan/Silaturahmi Antar Posko}

Silaturahmi adalah hal yang sangat penting dan mulia di mata sang pencipta. Maka dari itu kami KKN 06 melakukan kunjungan ke beberapa posko atau kelompok lain yang tidak jauh dari posko kami dan juga salah satu posko dari UIN Jakarta.

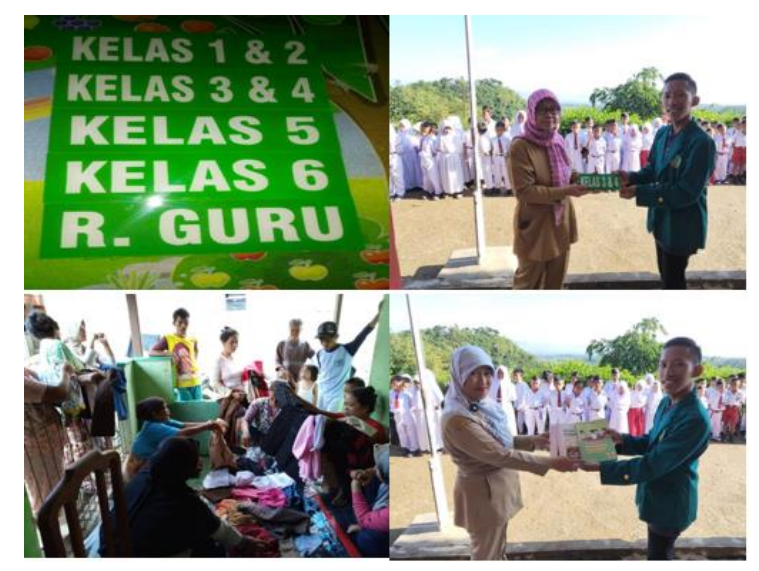

Pemberian Donasi Buku, Plang Nama Kelas dan Pakaian

Kami dari KKN 06 UIKA 2018 membuka donasi untuk warga kampung sinar wangi tentang baju bekas layak pakai dan buku untuk di sumbangkan kepada sekolah dan warga sekitar.

\section{KESIMPULAN}

Kegiatan KKN dengan sasaran masyarakat Desa Tapos Satu di kampong sinar wangi secara umum berjalan dengan lancar sesuai apa yang direncanakan, meski target waktu yang direncanakan tidak dapat sepenuhnya dijalankan sesuai dengan hal tersebut, namun hal tersebut tidak merubah esensi pelaksanaan program tersebut. Adapun kesimpulan dari pelaksanaan program kerja $\mathrm{KKN}$ masyarakat yaitu : 
a. Program KKN dapat terlaksana dengan baik dan lancar meski ada beberapa perubahan dan tambahan serta waktu pelaksanaan yang kurang sesuai dengan yang direncanakan.

b. Program Kerja KKN dapat berjalan dengan baik dengan perantara serta dukungan dan kerja sama antar warga yang sangat membantu.

Dengan demikian, hasil kesimpulan diatas menunjukkan bahwa secara garis besar program KKN dapat dikatakan sukses dan lancar, meskipun waktunya lebih maju atau lebih mundur

KKN merupakan kegiatan dengan pemberian akses pada mahasiswa untuk terjun langsung ke masyarakat dan menyalurkan ilmu yang di dapat. Hal ini ditujukan untuk melatih mahasiswa dalam hidup bermasyarakat serta untuk memberdayakan masyarakat dengan cara meningkatkan kreativitas dan kemampuan, membantu masyarakat melakukan fungsi keluarga melalui program-program .

Dalam bidang Pendidikan, kampung sinar wangi masih sangat minim dalam hal

\section{SARAN}

Berdasarkan hasil pelaksanaan program KKN yang dilaksanakan sejak 7 Agustus 2018 sampai 5 September 2018, terdapat beberapa saran yang sekiranya membangun bagi semua pihak, antara lain:

a) Program-program yang telah dilaksanakan oleh mahasiswa dan masyarakat, sebaiknya ada pengembangan ataupun tindak lanjut untuk peningkatan selanjutnya.

b) Dalam Bidang Pendidikan perlunya perhatian lebih dari orang tua terhadap kemajuan pendidikan anak dan memberikan hak yang sudah sepantasnya mereka dapatkan dalam hal perhatian terhadap pentingnya pendidikan, khususnya pendidikan untuk anak usia dini. Hal tersebut terlihat dari kurangnya kesadaran orang tua yang harus memiliki semangat tinggi menyekolahkan anaknya. Pemberian bimbingan belajar atau jam tambahan belajar untuk siswa SD dan SMP merupakan salah satu hal penting yang harus diperhatikan, karena kemampuan anak dengan tingkat pendidikan yang ditempuh sesuai dengan yang diharapkan.

Dalam bidang Kesehatan di kampung sinar wangi masih belum bisa dikatakan cukup, dikarenakan hanya satu bulan sekali posyandu diadakannya.

Dalam bidang Ekonomi sudah lebih baik karena adanya menabung sejak dini agar anak-anak terbiasa menabung atau menyisihkan uangnya dengan menabung, agar bisa menanamkan budaya menabung sejak dini.

Dalam bidang Pemberdayaan Lingkungan masyarakat disana sangat baik dan ramah sangat menyambut mahasiswa yang KKN.

ini adalah ilmu pengetahuan. Perlunya juga peran serta pemerintah desa dalam meninjau anak-anak apakah mereka sudah mendapatkan hak dan kewajiban mereka sebagai pelajar. Adakan juga penyuluhan secara berkala baik itu pada peserta didik dan orang tua untuk meningkatkan motivasi pendidikan. Meningkatkan kualitas pendidikan dengan menyediakan prasarana yang memadai dan sdm yang kompeten.

c) Dalam Bidang Kesehatan perlunya peran serta pemerintah dalam memperhatikan masyarakatnya. Adakan posyandu dan pengecekan kesehatan 
secara lebih rutin lagi guna mengetahui apakah masih ada masyarakat tidak mampu untuk membayar biaya rumah sakit.

d) Dalam Bidang Ekonomi adakan pelatihan untuk warga dalam mengolah sumber daya alam dan manusia yang ada secara rutin. Perlu juga diajarkan cara bercocok tanam dan panen yang baik agar hasilnya juga baik.

\section{REFERENSI}

Buku Pedoman KKN UIKA 2018

Petunjuk Pelaksanaan KKN Tematik Terintegrasi 2018. Bogor : LPPM UIKA

Pedoman Pelaporan PPM UIKA 2017. Bogor. LPPM UIKA

http://obatnet.blogspot.com/2014/02/lalapanmanfaat-daun-poh-pohan

https://www.aryanto.id/artikel/id/1953/kha siat-dan-manfaat-daun-pohpohan$\underline{\text { untuk-kesehatan }}$

http://www.kinisehat.com/2016/04/manfaa t-pohpohan-kesehatan-kecantikan

https://manfaat.co.id/manfaat-daunpohpohan

https://www.deherba.com/daun-kucai
Tumbuhkan jiwa kewirausahaan pada setiap warga agar bisa menjadi seorang wirausaha yang sukses.

e) Dalam Bidang Pemberdayaan Lingkungan bahwa mereka harus lebih peka terhadap lingkungan sekitar dan orang baru agar lebih antusias dan membantu setiap kegiatan yang dilaksanakan.

http://thekucai.blogspot.com/2012/02/apaitu-kucai-dan-apa-saja-khasiatnya

http://hidayahnr18.blogspot.com/2016/12/p engertian-kesadaran-manusia

https://bdksemarang.kemenag.go.id/konsep -kesadaran-diri-dan-kemauanbelajar-mandiri-sebagai-dasarmodel-pembelajaran-inquiry-di-erapendidikan-modern/

https://pgsd.binus.ac.id/2016/12/26/kepriba dian-dalam-pendidikan/

http://www.referensimakalah.com/2012/04 /pengertian-kepribadian-dalampendidikan

http://gudangpengertian.blogspot.com/201 4/10/pengertian-kesehatan-secaraumum

http://belajarpsikologi.com/pengertiankesehatan/ 